\title{
PREVALENCE OF STAPHYLOCCUS AND AEROMONAS IN SOME SALTED DAIRY PRODUCTS
}

\author{
AHMED HASSAN SAAD ${ }^{1}$; EHAB MOHAMED SALAMA ${ }^{1}$; HANAN A. EL DAHSHAN ${ }^{2}$ \\ and NOHA TALAAT ASSAF ${ }^{1}$ \\ ${ }^{1}$ Faculty of Veterinary Medicine, Suez Canal University, Egypt \\ ${ }^{2}$ Food Hygiene Department, Port-Said Branch, Animal Health Research Institute
}

Received: 18 November 2018; Accepted: 9 December 2018

\begin{abstract}
120 samples of pickled white soft cheese (domiata cheese) and Mish were collected from local markets in Port Said governorate, Egypt. Samples were analyzed for sodium chloride level, determination of Staph. Spp at 3\% and $10 \% \mathrm{Na} \mathrm{CL}$, isolation of Staphylococcus aureus at 3\% and 10\% NaCL and Determination of Aeromonas spp. at $3 \%$ and $10 \% \mathrm{NaCL}$. Results obtained revealed that the mean values of the sodium chloride percentage were $3.7 \pm 0.13 \%$ in pickled domiata cheese samples and $6.1+0.14 \%$ in mish samples. Incidence of Staph. spp in Pickled domiata cheese was $85 \%$ at $3 \% \mathrm{NaCL}$ and $71.6 \%$ at $10 \% \mathrm{NaCL}$. while in mish samples was $93 \%$ at $3 \%$ $\mathrm{NaCL}$ and $83.3 \%$ at $10 \% \mathrm{NaCL}$. Incidence of Aeromonas spp.at $3 \% \mathrm{NaCL}$ was nil while at $10 \% \mathrm{NaCL}$ was 48.3\% in pickled domiata cheese and in Mish 38.3\% in. Incidence of A. hydrophila, A. caviea, A.trota and A.schubertii in Pickled domiata cheese were $25.7 \%, 40 \%, 20 \%$ and $14.3 \%$, respectively. While in Mish were $25 \%, 46.4 \%, 21.4 \%$ and $7.1 \%$ respectively.
\end{abstract}

Key words: Salted dairy products, halophilic bacteria, Staph. Spp., Aeromonas spp.

\section{INTRODUCTION}

Pickled white soft cheese (domiata cheese) and Mish are well-known as local types of cheese in Egypt. Handling of milk during cheese manufacture considered the main source of microbial contamination of cheese which affecting on cheese quality and render it unfits for human consumption (Yousef et al., 2001).

Staphylococcus spp. are considering one of halophilic bacteria which its presence in milk or milk products can cause a public health hazard, Staphylococcus aureus is responsible for food poisoning (ICMSF, 1986) S. aureus is consider as one of important food-borne pathogen. It is a versatile pathogen of humans and animals; it causes a wide variety of diseases ranged in severity from slight skin infection to more severe diseases such as pneumonia and septicemia (Lowy, 1998). Staph.aureus is capable of producing several enterotoxin cause food poisoning in human with varying degree and generally characterized by nausea, diarrhea, abdominal cramps and emesis

Corresponding author: HANAN A. EL DAHSHAN

E-mail address: mhananamen@yahoo.com

Present address: Food Hygiene Department, Port-Said Branch, Animal Health Research Institute
(Normanno et al., 2005) and (Brightwell et al., 2006). In the last few decades' Staphylococcal food poisoning (SFP) has been reported as third cause of food-borne illnesses in the world (Zhang et al., 1998).

Aeromonas spp are considered one of the most important halophilic bacteria which are widely distributed in nature. Moreover it is considered as food borne pathogen (Palumbo et al., 1992). Aeromonas spp. is pathogens that cause food-borne gastroenteritis, extra intestinal symptoms such as septicemia, meningitis, endocarditis and osteomyelitis with a high mortality rate in immunecompromised person (Gold and Salit, 1993). The mechanisms by which Aeromonas spp. cause diarrhea has been known that they produce enterotoxins, certain enzymes, they are able to adhere cell membranes and invade them (Kirov et al., 1994). The presence of such bacteria in milk products may be due to direct contact with contaminated sources in dairy farm environment, excretion from udder of an infected animal or during processing of cheese. (Oliver et al., 2005).

\section{MATERIALS AND METHODS}

\section{Collection of samples}

One hundred and twenty random samples of pickled white soft cheese and Mish (60 of each) were collected from different markets in Port Said city, 
and then taken aseptically to the laboratory immediately, where it is subjected to chemical and microbiological examinations.

\section{Preparation of samples (A.P.H.A. 2004)}

$250 \mathrm{gm}$. of each sample were transferred aseptically in a sterilized polyethylene sac and thoroughly mashed in a sterile blender before being emulsified in the diluent solution under aseptic condition then divided into two subsamples for chemical examination and bacteriological examination.

\section{Chemical Examination}

3.1. Determination of sodium chloride content (A.O.A.C, 2000)

3 grams of prepared sample were weighted in 200 ml Erlyn - Meyer flask. $25 \mathrm{ml}$ of N/10 silver nitrate solution, $10 \mathrm{ml}$ of halogen free nitric acid and $50 \mathrm{ml}$ of distilled water were added and the mixture was boiled. $15 \mathrm{ml}$ of $5 \%$ potassium permanganate solution in $5 \mathrm{ml}$ portion were added during boiling (till the solution become yellowish and clear). Then the solution was allowed to cool then filtered into $200 \mathrm{ml}$ volumetric flask, the filter paper was washed thoroughly with distilled water at $20^{\circ} \mathrm{c}$, and the filtrate was made up to standard volume. The excess of silver nitrate in $100 \mathrm{ml}$ of the clear solution was titrated against $0.1 \mathrm{~N}$ potassium thiocyanate solution (9.71 g / liter) using $2 \mathrm{ml}$ of saturated solution of iron alum as indicator. The salt content was calculated according to the following equation:

$$
\begin{aligned}
\mathrm{Na} C L \%= & 2(25-\mathrm{R}) \mathrm{X} 0.00584 \times 100 \\
& \text { Weight }(3 \mathrm{~g})
\end{aligned}
$$

\section{Microbiological Examination}

\subsection{Determination of total Halophilic bacterial counts (A.P.H.A.2004)}

\section{Preparation of serial dilution:}

$10 \mathrm{gm}$ of each sample was transferred in sterile stomacher bag with $90 \mathrm{ml}$ synthetic sea water solution $(3 \% \mathrm{NaCL}$ for Slight or $10 \% \mathrm{NaCL}$ for moderate Halophilic counts). Apply in a stomacher lab-blender (2000 rpm) used to homogenize the specimen for 2 minutes to make a1:10 dilution (wt/vol) then decimal dilution of $10^{-2}, 10^{-3}, 10^{-4}, 10^{-}$ 5 and $10^{-6}$ were prepared.

$0.1 \mathrm{ml}$ from each dilution was inoculated in duplicated plates containing standard plate count agar following by spread plate technique and the plates were incubated at $37^{\circ} \mathrm{C}$ for 48 hours, then the total slight and moderate halophiles were counted and expressed as $\mathrm{CFU} / \mathrm{g}$.

\subsection{Identification of isolated Staphylococci organisms according to (FDA, 2001).}

Suspected colonies of Staphylococcus organisms were examined morphologically, microscopically according to (Ryan and Ray 2004)

4.3 Biochemical examination: according to (FDA, 2001)

The biochemical tests were Coagulase test, Catalase test, DNase test, Acetoin production, Oxidase test and D-mannitol fermentation.

\subsection{Isolation of Aeronomas spp.}

$10 \mathrm{gm}$ of each sample were homogenized with $90 \mathrm{ml}$ alkaline peptone water (with $3 \%$ or $10 \% \mathrm{NaCL}$ ) for $2 \mathrm{~min}$, and then incubated for $24 \mathrm{hr}$ at $30^{\circ} \mathrm{C}$ (Villari et al., 2000). A loopful from alkaline peptone water was subsequently plated on the surface of starch ampicillin agar plate and incubated for $48 \mathrm{hr}$. at $30^{\circ} \mathrm{c}$. Typical yellow colonies of Aeromonas species were purified on tryptone soya agar then stained by Gram's stain (A.P.H.A., 2004) and confirmed on the basis of the following test: Oxidase test, resistance to vibriostatic agent o/129, esculin hydrolysis, sugar fermentation and gas production, indole production and voges- proskaur test.

\subsection{Differentiation of common motile Aeromonas isolated.}

From clinical specimens according to Carnhan et al. (1991) as modified by Joseph and Carnahan (1994). All bacterial isolates would be short $\mathrm{G}$-ve bacilli, oxidase positive that ferment glucose.

\section{RESULTS}

\section{Sodium chloride content}

Table 1: Statistical analytical results of salt conc. \% in Pickled domiati cheese samples (n=60) and Mish samples $(\mathrm{n}=60)$ comparison with Egyptian Standards 2005

\begin{tabular}{ccccc}
\hline samples & Min. & Max. & Mean \pm SE & E.S 2005 \\
\hline Pickled domiati cheese & $2.9 \%$ & $5.3 \%$ & $3.7 \pm 0.135$ & Not more than $7.0 \%$ \\
\hline Mish & $4.2 \%$ & $8.3 \%$ & $6.1 \pm 0.142$ & Not more than $15 \%$ \\
\hline
\end{tabular}


Determination of total Slight \& moderate Halophilic counts

Table 2: Statistical analytical results of Total Slight and moderate Halophilic count in examined samples.

\begin{tabular}{ccccccc}
\hline \multirow{2}{*}{$\begin{array}{c}\text { Examined samples } \\
(\mathbf{n = 6 0})\end{array}$} & \multicolumn{2}{c}{ Positive samples } & \multicolumn{2}{c}{ Count (cfu/g.) } \\
\cline { 2 - 6 } & $\mathbf{3 \% \text { Nacl }}$ & 49 & 81.6 & $1 \times 10^{3}$ & $1 \times 10^{6}$ & $3.31 \times 10^{5} \pm 0.81 \times 10^{5}$ \\
\hline \multirow{2}{*}{$\begin{array}{c}\text { Pickled domiati } \\
\text { cheese }\end{array}$} & $\mathbf{1 0 \% ~ N a c l}$ & 46 & 76.6 & $1 \times 10^{2}$ & $3.2 \times 10^{5}$ & $0.76 \times 10^{5} \pm 0.14 \times 10^{5}$ \\
\cline { 2 - 6 } Mish & $\mathbf{3 \% ~ N a c l}$ & 56 & 93.3 & $1.6 \times 10^{3}$ & $2.6 \times 10^{6}$ & $1.99 \times 10^{5} \pm 0.42 \times 10^{5}$ \\
\cline { 2 - 6 } & $\mathbf{1 0 \%}$ Nacl & 58 & 96.6 & $5 \times 10^{2}$ & $9 \times 10^{5}$ & $2.09 \times 10^{5} \pm 0.36 \times 10^{5}$ \\
\hline
\end{tabular}

Detection of Staphylococcal organisms at $3 \%$ and $10 \%$ NaCL:

Table 3: prevalence of Staphylococci isolated from examined samples.

\begin{tabular}{|c|c|c|c|c|c|}
\hline \multirow{3}{*}{ Examined samples } & \multirow{3}{*}{ No. } & \multicolumn{4}{|c|}{ Positive samples } \\
\hline & & \multicolumn{2}{|c|}{$3 \% \mathrm{NaCL}$} & \multicolumn{2}{|c|}{$10 \% \mathrm{NaCL}$} \\
\hline & & No. & $\%$ & No. & $\%$ \\
\hline Pickled domiati cheese & 60 & 51 & 85 & 43 & 71.6 \\
\hline Mish & 60 & 57 & 93 & 50 & 83.3 \\
\hline
\end{tabular}

\section{Isolation of Aeronomas spp. at $3 \%$ and $10 \% \mathrm{Na} \mathrm{CL}$}

Table 4: Incidence of Aeromonas spp. in examined samples at $10 \% \mathrm{NaCl}$.

\begin{tabular}{|c|c|c|c|c|c|c|c|c|c|c|c|c|c|}
\hline \multirow{3}{*}{$\begin{array}{l}\text { Types of } \\
\text { Examined } \\
\text { samples }\end{array}$} & \multirow{3}{*}{$\begin{array}{c}\text { No. of } \\
\text { Examined } \\
\text { samples }\end{array}$} & \multirow{2}{*}{\multicolumn{2}{|c|}{$\begin{array}{l}\text { Positive } \\
\text { samples }\end{array}$}} & \multirow{2}{*}{\multicolumn{2}{|c|}{ isolates }} & \multicolumn{8}{|c|}{ Aeromonas spp } \\
\hline & & & & & & \multicolumn{2}{|c|}{$\underset{\text { hydrophila }}{A .}$} & \multicolumn{2}{|c|}{ A. caviae } & \multicolumn{2}{|c|}{ A. trota } & \multicolumn{2}{|c|}{$\begin{array}{c}\text { A. } \\
\text { schubertti }\end{array}$} \\
\hline & & No & $\%$ & No. & $\%$ & No. & $\%$ & No & $\%$ & No & $\%$ & No & $\%$ \\
\hline $\begin{array}{c}\text { Pickled } \\
\text { domiati } \\
\text { cheese }\end{array}$ & 60 & 29 & $48.31 \%$ & 35 & $58.3 \%$ & 9 & $25.7 \%$ & 14 & $40 \%$ & 7 & $20 \%$ & 5 & $14.3 \%$ \\
\hline Mish & 60 & 23 & $38.3 \%$ & 28 & $46.6 \%$ & 7 & $25 \%$ & 13 & $46.4 \%$ & 6 & $21.4 \%$ & 2 & $7.1 \%$ \\
\hline
\end{tabular}

\section{DISCUSSION}

\section{Sodium chloride content}

The use of salting is one of the classical methods of food preservation. Salting is used to extend the shelf-life of foods throughout civilization. In this study, it is evident in table (1) that salt percentage of examined pickled domiati samples ranged from 2.90 $\%$ to $5.30 \%$. While in mish samples ranged from
$4.20 \%$ to $8.30 \%$ all results obtained were within the normal range of (Egyptian Standards, 2005). Nearly similar results were reported by Ceylan et al. (2003), Hassan and Afify, (2007), Nawar, (2007), ELAnsary et al. (2011), El Bakry, (2012), Yasser, (2015) and EL-Refaay, (2016), while higher result were obtained by Mohamed, (2004), Patrick et al., (2004), Hayaloglu and Kirbag, (2007) and EL Zahar, 
(2010). While lower result were obtained by Riad, (1996) and Sadek, (2009).

\section{Determination of total Slight \& moderate Halophilic counts}

Slight, moderate, and extreme halophiles as those bacteria that grow best in media containing 2 to $5 \%$, 5 to $20 \%$ and 20 to $30 \%$ salt respectively. (Kushner 1978). in table (2) Samples examination refer that maximum value of slight halophilic count in Pickled domiati cheese samples and Mish samples were 1x $10^{6}$ and $2.6 \times 10^{6}$ respectively while minimum value were $1 \times 10^{3}$ and $1.6 \times 10^{3}$ respectively where salt conc. was $3 \%$. This results are nearly similar to Freitas et al. (1993), and Saad and Moawad (1999). While higher results are obtained by Riad (1996) and Omer et al. (2007).

The maximum value of moderate halophilic count in Pickled domiati cheese samples and Mish were $3.2 \mathrm{x}$ $10^{5}$ and $9.0 \times 10^{5} \mathrm{cfu} / \mathrm{g}$. respectively, while minimum value was $1.0 \times 10^{2}$ and $5.0 \times 10^{2} \mathrm{cfu} / \mathrm{g}$. Respectively with mean value $0.76 \times 10^{5} \pm 0.14 \times 10^{5}$ in pickled domiati cheese samples. And with mean value 2.09 $\mathrm{x} 10^{5} \pm 3.6 \times 10^{4}$ in Mish samples (Where NaCL concentration is 10\%). These results are nearly similar to El-prince (1994) and Riad (1996), while lower results are obtained by Omar et al. (2007).

\section{Detection of Staphylococcal organisms at $3 \%$ and 10\% NaCL:}

The presence of Staphylococcus is an index of contamination from operators or workers. It has a potential significance to public health due to its ability to produce enterotoxin leading to food poisoning. The results in Table (3) show that incidence of Staphylococcus in Pickled domiati cheese was $85 \%$ at $3 \% \mathrm{NaCL}$ and $71.6 \%$ at $10 \%$ NaCL. While in Mish samples was $93 \%$ at $3 \%$ $\mathrm{NaCL}$ and $83.3 \%$ at $10 \% \mathrm{NaCL}$. These results are nearly similar to those obtained by Abou ElMakarem, (2009). Higher results are obtained by Sheleby(2008) and Elshafey (2011).

\section{Isolation of Aeronomas spp. at $3 \%$ and $10 \% \mathrm{Na}$ CL:}

Aeromonas species are widely distributed in the aquatic environment, including raw and processed drinking water (Holmes et al., 1996), and have been frequently isolated from various food products such as fish and shellfish, raw meat, vegetables and raw milk Palumbo, (1996). It is associated with travellers' diarrhea (Hänninen et al., 1995 and Yamada et al., 1997). In this study, Aeromonas species was not isolated from any examined samples either Mish or Pickled domiati cheese using $3 \%$ salt concentration while at $10 \% \mathrm{Na}$ $\mathrm{CL}$, as shown in table (4) that the incidence of Aeromonas spp. was $25 \%$ A.hydrophila, $46.4 \%$ A.caviae, $21.4 \%$ A trota and $7.1 \%$ A. schubertti in Mish cheese samples while the incidence of
Aeromonas spp. was $25.7 \%$ A.hydrophila, $40 \%$ A.caviae, $20 \%$ A. trota and $14.3 \%$ A. schubertti in Pickled domiati cheese samples. This results are nearly similar to those obtained by to Freitas et al. (1993), Khalil (1997), Effat et al. (2000), Ahmed et al. (2014) Higher results are obtained by Yasser (2008), Nazem et al. (2010) and Alhazmi (2015).

\section{REFERENCES}

Abou El-Makarem, H.S.M. (2009): Plasmid profile from several pathogenic microorganism strains isolated from market kareish cheese M.V.Sc. Thesis, Faculty of Vet. Med. Alex. University.

Ahmed, N.I.; Abd-Aal, S.F.; Madeha, A.A. and ElSayed, M.S. (2014): Enumeration of Aeromonas spp. isolated from milk and some dairy products in Sharkia Governorate Egypt. Alexandria journal of veterinary science 40 (1), 52-63.

Alhazmi, M.I. (2015): Isolation of Aeromonas spp. from food products: Emerging Aeromonas infections and their significance on puplic heatlh.Journal of AOAC international, 97(4): 927-929.

A.P.H.A. (2004): American Puplic Health association: Standard Methods for the Examination of Daiy Products. $17^{\text {th }}$ ed, APHA, Washington D.C.USA.

A.O.A.C. (2000): Association of Official Analytical Chemists 17th Ed.pub.A.O.C.A.POBOX540, Benjamin Franklin station Washington, D.C.

Bightwell, G.; Clemens, R. and Boerma, J.A. (2006): Evalution of molecular methods to determine enterotoxigenic status and molecular genotype of bovine, ovine, human and food isolates of Staphylococcus aureus. International Journal of food Microbiology, 107 (2): 192-201

Carnahan, A.M.; Behram, S. and Joseph, S.W. (1991): AerokeyII: a flexible key for identifying clinical Aeromonas spescies. Journal of clinical Microbiology 29 (12); 2843-2849.

Ceylan, Z.; Turkoglu, H. and Dayisoylu, K.S. (2003): The microbial and chemical quality of Sikma cheese produced in Turkey. Pakistan journal of Nutrition, 2(2): 95-97.

EL-Refaay, D.G.A. (2016): Mycological studies on some types of cheese. M.V.Sc., Thesis., Fac. Vet. Med. Sues Canal University.

Egyptian Standards (2005): Mish cheese. Egyptian Organization for Standardization and Quality Control, Es.4342/2008.

Effat, B.A.; Hosny, I.M. and Dabiza, N.M. (2000): Occurrence of Aeromonas hydrophila and its growth in Egyptian soft cheese. Egyptian Journal of Dairy Science, 28 (1): 1-12. 
EL-Ansary, M.A.M. (2011): Hygienic condition `of locally manufactured cheese. Ph. D. Thesis, Fac. Vet. Med. Alex. Univ., Egypt.

El-Bakry, M. (2012): Salt in cheese., current research in dairy sciences 4(1):1-5. Department of dairy science and technology, faculty of Agriculture, Cairo university, Giza, Egypt.

El shaffy, M.N. (2011): Genotypic characterization of Staphylococcus aureus as food poisoning organism from milk and dairy products., department of Bacteriology- immunitymycology. M.V.Sc. Thesis. Fac. Vet. Med. Suez Canal Uni.

El-Zahar, K.M.; Hendawi, M.Y. and Abdel-Zaher, A.M. (2010): Evaluation of biogenic amines in Egyptian cheese markets: the effects on physiological parameters of rats. Egyptian Journal of Dairy Science, 38 (2) 219-230.

El-prince, E.M. (1994): Effect of potassium sorbate on the microbiological quality of milk and some milk products. Ph.D. Thesis, Fac. Vet. Med. Assiut University.

FDA; Food Drug Administration (2001): Analytical manual. Chapter12, Staphylococcua aureus. Reginal W.B and Gayle A.I.

Freitas, C.A.; Marly, P.N.; Arlete, M.M. and Ilvan, D. Ricciadi (1993): Occurance and characterization of Aeromonas species in pasteurized milk and white cheese in Rio de Janeiro, Brazil Journal of food protection. Vol.56(1): 62-65.

Gold, W.L. and Salit, I.E. (1993): Aeromonas hydrophila infections of the skin and softtissue: Report of 11 cases and review. Clin. Infect. Dis., 16: 69-74.

Hanninen, M.L.; Salmi, S.; Mattila, L.; Taipalinen, R. and Siitonen, A. (1995): Association of Aeromonas spp. with travellers' diarrhea in Finland. Journal of Medical microbiology 42, 26,31 .

Hassan, G.M. and Afify, S.I. (2007): Occurance of some pathogenic microorganisms in Kareish cheese and their puplic health significance. Beni Suif vet. Med. Journal pp.142-150.

Hayaloglu, A.A. and Kirbag, S. (2007): Microbial quality and presence of moulds in Kuflu cheese. International journal of food microbiology, 115(3): 376-380.

Holmes, P.; Niccolls, L.M. and Sartory, D.P. (1996): The ecology of mesophilic Aeromonas in the aquatic environment. In the Genus Aeromonas ed. Austin, B., Altwegg, M., Gosling, P.J. and Joseph, S.pp.127-150. Chichester, UK: Wiley and Sons.

ICMSF (International Commission on Microbiological Specification for Food (1986): Microbial Ecology of Food, Vol.1-2. University of Toronto Press.

ISO (1999): International organization for standardization. Microbiology of food and animal feeding stuffs- Horizontal method for the detection of Staphylococcus.

Mohamed, I.M.J. (2004): Biogenic amines and their forming organisms in cheese. Ph.D. Thesis, Fac. Vet. Med, Suez Canal Uni.

Joseph, S.W. and Carnahan, A. (1994): The isolation, identification and systematics of the motile Aeromonas species. Annual review of fish disease. 4, 315-343.

Khalil, N.G. (1997): Incidence of Aeromonas hydrophila group in raw milk and some dairy products in Assuit City. Assuit Vet. Med. J. 37(73): 100-108.

Kushner, D.J. (1978): Life in high salt and solute concentrations: halophilic bacteria, in D.J. Kushner, Ed. Microbial life in Extrem Enviroments, Academic press, New York. p. 317

Kirov, S.M.; Hudson, J.A.; Hayward, J. and Mott, S.J. (1994): Distribution of Aeromonas hydrophila hybridization groups and their virulence properties in Australasian clinical and environmental strains. Lett. Appl. Microbiol., 18: 71-3.

Lowy, F.D. (1998): Staphylococcus aureus infection. N. Engl. J. Med. 339: 520-532.

Nawar, D.M.M. (2007): Toxico-infection organisms in milk and some street-vended dairy products. Ph. D. Thesis, Fac. Vet. Med., Alex. Univ., Egypt.

Nazem, A.M.; Amer, A.A. and Soukayna, Abd ElAhad (2010): Prevalance of some food poisoning micoorganisms in some dairy products. Alex.j. vet.30 (1): 1-6.

Normanno, G.; Firinu, A.S.; Virilio, G.; Mule, A.D.; Poggiu, A.; Decastelli, L.; Mioni; R.; Scuta, S.; Bolzoni, G.; Di Giannatale, E.; Salinetti, A.P.; La Salandra, G.; Bartoli, M.; Zuccon, F.; Pirino, T.; Sias, S.; Parisi, A. and Celano, G.V. (2005): Coagulase-positive Staphylocci and Staphylococcus aureus in food products in marketed in Italy. International journal of food microbiology. 98. (1) (15): 73-79.

Oliver, S.P.; Jayarao, B.M. and Almeida, R.A. (2005): Food borne pathogens in milk and the dairy farm environment. Food safety and public health implications, 2(2): 115-129.

Omar, H.; Hoda, A.E.; Wafaa, M.B. and Naglaa F.G. (2007): Bacteriological quality of some dairy products (Kariesh cheese and Ice cream) in Alexanderia. Microbiology Dep. Alex. University. Food hygein and control Division, Nutrition Department, Egypt puplic Health Assoc.Vol.82.No.586.

Palumbo, S.A.; Abeyta, C. and Stelma, G. (1992): Aearomonas hydrophila group. In compendium of mothods for the microbiological examination of foods (Eds Vanderzat, C. and Splittstoesser, D.F.) PP.497-515, Washington, D.C., American Public Health Association. 
Palumbo, S.A. (1996): The Aeromonas hydrophila group in food. in The Genus Aeromonas ed. Austin, B., Altwegg, M., Gosling, P.J. and Joseph. S., pp.287-310. Chichester, UKWiley and Sons.

Patrick, F.; Fox, M.; Cogan, T.M. and Timothy, G. (2004): Cheese Chemistry, Physics and Microbiology: Major Cheese Groups: Major Cheese Groups v. 2

Rayan, K.J. and Ray, C.G. (Eds). (2004): Sherris Medical Microbiology $4^{\text {th }}$ ed. McGraw Hill, New York.

Riad, A.M.A. (1996): Microbial monitoring for some dairy products as indices of sanitary quality, Ph. thesis. Fac. Vet. Med. Alex. Uni.

Saad, A.H. and Maawad, A. (1999): Incidence of slight and moderate Halophiles in some selected food. Beni-Suef Veterinary Medical Journal, 9(3-A): 37-49.

Sadek, S.M. (2009): Grading quality of some locally manufactured milk products. M.V.Sc. Thesis, Fac. Vet. Med., Alex Univ., Egypt.

Sheleby, H.H.A. (2008): Indicator Organisms in Street-Vended Dairy Products. M.V.Sc. Thesis, Fac. Vet. Med., Minufiya University.

Villari, P.; Crispino, M.; Montuori, P. and Stazione, S. (2000): Prevalance and Molecular characterization of Aeromonas spp.in Ready-
to-Eat foods in Italy. Department of Health and Praventive Science. University Federico II. Journal of food protection. 63(12): 17541757.

Yamada, S.; Matsushita, S.; Dejsirilet, S. and Kudoh, Y. (1997): Incidence and clinical symptoms of Aeromonas-associated Traveller's diarrhea in Tokyo. Epidemal infect. 199, 121-126.

Yasser, A.M. (2008): Prevelance of Aeromonas hydrophila group in milk and milk products., Cairo university, faculty of Veterninary Medicine, department of food hygiene.

Yasser, S.I.S. (2015): Incidence and Biocontrol of Staph. Aureus in some milk products. M.V. SC. Thesis. faculty of Vet. Med. Suez Canal University.

Yousef, H.; Sobieh, M. and Nagedan, K. (2001): Microbial status of Domiati cheese at $\mathrm{Al}$ Gassiem area, Saudi Arabia., $8^{\text {th }}$ sci. Cong., The fac. vet. Med. Assiut University, pp: 9197.

Zhang, S.; Iandolo, J.J. and Stewart, G.C. (1998): The enterotoxin D plasmid of Staphylococcus aureus encodes a second enterotoxin determinant (sej). FEMS Microbiology Letters, 168: 227-233.

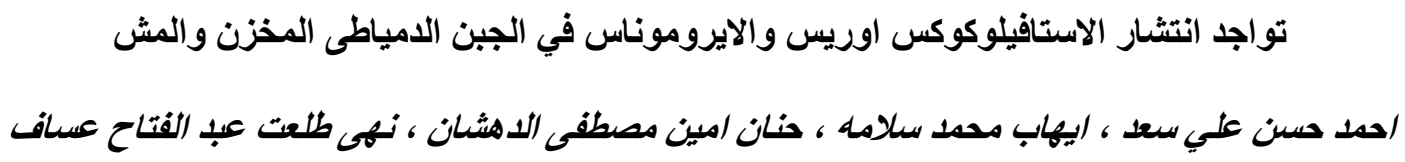

Email: mhananamen@yahoo.com Assiut University web-site: www.aun.edu.eg

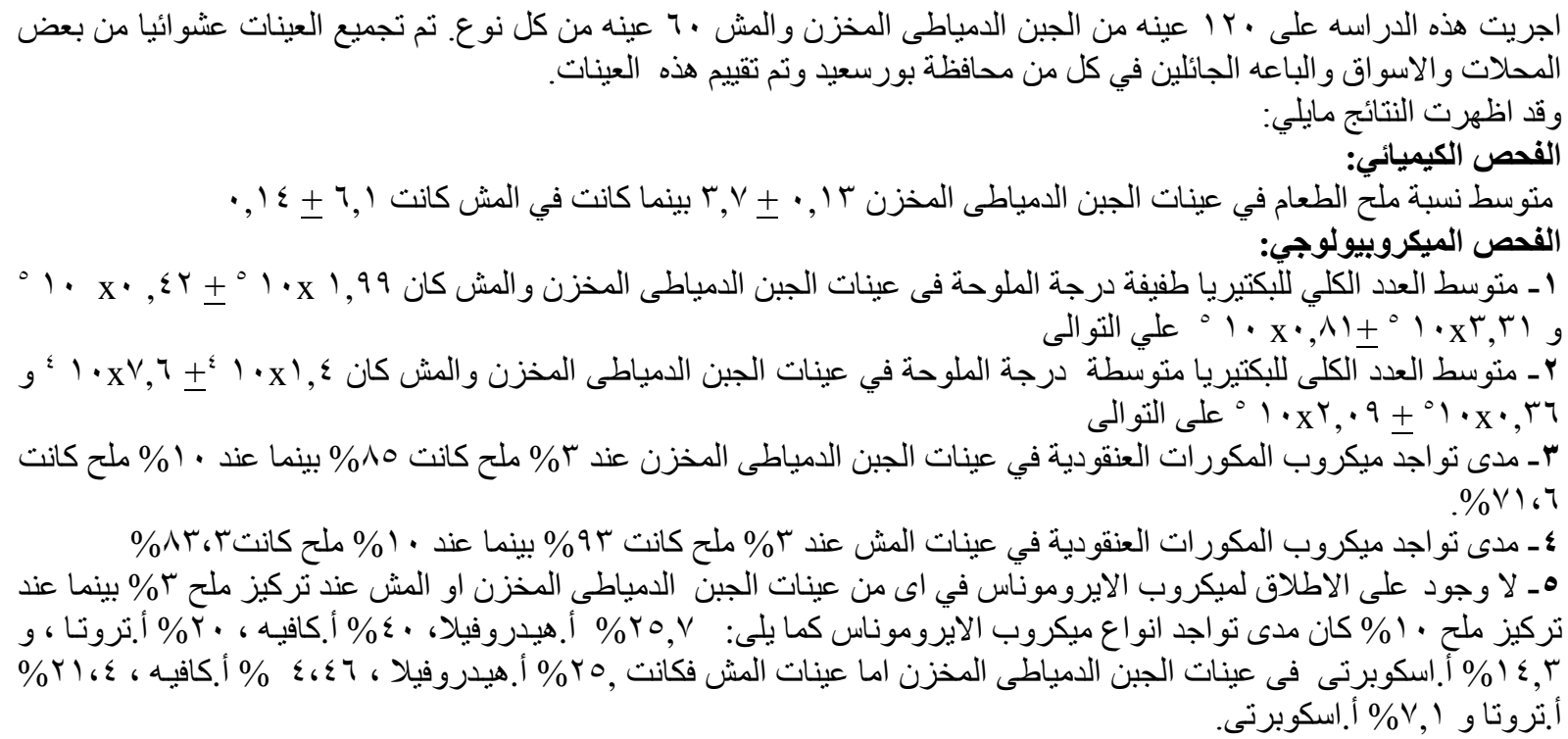

